\title{
Kombinasi Jenis Pasir dengan Serat Batang Aren serta Pengaruhnya terhadap Pertumbuhan dan Hasil Tomat secara Hidroponik Substrat
}

\author{
Combination of Sand Types with Arenga Wood Fiber on Tomato's \\ Growth and Yield by Substrate Hydroponically
}

Shufiyati Muniroh ${ }^{1)}$, Dwi Harjoko ${ }^{2)}$, Sumiyati ${ }^{2)}$

\section{ABSTRACT}

This study aims to measure the effect of volcanic sand, native sea sand and sea sand washing substrate on the growth and yield of tomatoes, measuring the effect of arengan wood fiber substrate on growth and yield of tomatoes, measuring the effect of the combination of volcanic sand, native sea sand and sea sand washing with arenga wood fiber substrate compared to the growth and yield of tomato. The research was conducted from August to December 2014 in the screen house Faculty of Agriculture, Sebelas Maret University. This study uses a completely randomized design with 1 factors with 14 treatment. The analysis of the data was tested using the $\mathrm{F}$ test level of $5 \%$. After that, if the result $\mathrm{F}$ tests $5 \%$ significant, the analysis continued with DMRT (Duncan Multiple Range Test) level of $5 \%$. The results showed treatment volcanic sand, native sea sand and sea sand washing substrate produce growth and good results in tomatoes when watering is often done so that the plants do not wilt. Arenga wood fiber substrate treatment resulted in poor growth of the roots and results of tomatoes. Treatment volcanic sand, native sea sand sea sand washing genuine with arenga wood fiber (1:1) to produce growth and good results on tomato plants.

Keywords : tomato, volcanic sand, sea sand, arenga wood fiber

\section{PENDAHULUAN}

Budidaya tanaman yang dilakukan secara
konvensional
mengalami berkurangnya lahan pertanian, pupuk yang diberikan sebagian hilang terbawa air maupun menguap dan tergantung pada musim tanam. Masalah tersebut menjadikan produksi hasil pertanian menurun. Solusi untuk menangani masalah tersebut dengan budidaya hidroponik yang dapat dilakukan di screen house, rumah kaca, maupun atas bangunan. Penggunaan pupuk pada budidaya tanaman dapat diop-timalkan dengan menggunakan sistem hidroponik, nutrisi yang dibutuhkan tercukupi dan lebih efisien (Wasonowati 2011). Tomat merupa-kan salah satu tanaman yang produksinya lebih rendah dari potensinya. Produksi tomat perlu ditingkatkan dengan memperbaiki teknologi budidaya seperti perbaikan varietas, pengen-dalian hama penyakit, serta perbaikan pasca panen. Faktor lain yang menyebabkan produksi tomat rendah adalah penggunaan pupuk yang kurang optimal (Wasonowati 2011).

Tomat yang ditanam secara hidroponik memerlukan media sebagai tempat tegaknya dan sebagai tempat untuk menyimpan nutrisi yang dibutuhkan oleh tanaman. Serat aren merupakan limbah dari pembuatan tepung aren. Serat aren dapat digunakan merupakan media tanam organik untuk hidroponik. Pasir vulkanik masih sedikit yang

\footnotetext{
${ }^{1)}$ Undergraduate Student of Study Program of Agrotechnology, Faculity of Agriculture University of Sebelas Maret (UNS) in Surakarta.

2) Lecturer of Study Program of Agrotechnology, Faculity of Agriculture University of Sebelas Maret (UNS) in Surakarta.
}

Contact Author: dwi_hardjoko.yahoo.com memanfaatkannya sebagai media tanam. Pasir pantai memiliki ciri-ciri antara lain tekstur pasiran, struktur lepas-lepas, kandungan hara rendah, kemampuan menukar kation rendah, daya menyimpan air rendah, suhu tanah di siang hari sangat tinggi, laju evaporasi sangat tinggi (Yuwono 2009). Kombinasi antara serat aren dan pasir diharapkan dapat menjadi media yang baik untuk budidaya hidroponik.

Penelitian ini bertujuan untuk mengukur pengaruh substrat pasir vulkanik, pasir pantai asli dan pasir pantai cuci pada pertumbuhan dan hasil tomat, mengukur pengaruh substrat serat batang aren pada pertumbuhan dan hasil tomat, mengukur pengaruh kombinasi substrat pasir vulkanik, pasir pantai asli dan pasir pantai cuci dibanding serat batang aren pada pertumbuhan dan hasil tomat.

\section{METODE PENELITIAN}

Penelitian ini dilaksanakan pada bulan Agustus sampai Desember 2014. Penelitian dilakukan di tiga tempat yaitu screen house, Laboratorium Fisiologi Tumbuahan, dan Laboratorium Kimia dan Kesuburan Tanah Fakultas Pertanian Universitas Sebelas Maret Surakarta. Alat yang digunakan dalam penelitian ini yaitu polybag, gelas ukur, meteran EC meter, klorofil meter, timbangan analitik, oven. Bahan yang digunakan dalam penelitian ini adalah benih tomat varietas Permata F1, pasir vulkanik dicuci, pasir pantai tidak dicuci, pasir pantai dicuci, serat aren yang sudah digiling, air, larutan nutrisi $A B$ mix dan arang sekam.

Penelitian ini dirancang dengan Rancangan Acak Lengkap (RAL) dengan 1 faktor dengan 14 perlakuan, perlakuan serat batang aren diulang 15 kali dan perlakuan yang lain diulang 5 kali sehingga ada 80 tanaman. Adapun faktor perlakuan tersebut yaitu:

Adapun perlakuannya sebagai berikut: 
Pasir vulkanik dan serat batang aren (1:3)

Pasir vulkanik dan serat batang aren (1:1)

Pasir vulkanik dan serat batang aren (3:1)

Pasir vulkanik

Pasir pantai tidak dicuci dan serat batang aren (1:3)

Pasir pantai tidak dicuci dan serat batang aren (1:1)

Pasir pantai tidak dicuci dan serat batang aren (3:1)

Pasir pantai tidak dicuci

Pasir pantai cuci dan serat batang aren (1:3)

Pasir pantai cuci dan serat batang aren (1:1)

Pasir pantai cuci dan serat batang aren (3:1)

Pasir pantai cuci

Serat batang aren

Arang sekam.

Pelaksanaan penelitian mulai dari persiapan media, pembibitan, penanaman, perawatan dan panen. Pengamatan tanaman dibagi menjadi dua yaitu pengamatan pertumbuhan tanaman dan hasil panen. Pengamatan pertumbuhan meliputi tinggi tanaman, panjang akar, volume akar, rasio akar tajuk dan berat buah per tanaman.

Analisis data diuji menggunakan uji $\mathrm{F}$ taraf $5 \%$. Apabila uji $\mathrm{F} 5 \%$ signifikan maka dilanjutkan dengan DMRT (Duncan Multiple Range Test).

\section{HASIL DAN PEMBAHASAN}

\section{Kondisi Umum Lokasi Penelitian}

Penelitian ini dilaksanakan di screen house Fakultas Pertanian Universitas Sebelas Maret Surakararta dengan ketinggian tempat $95 \mathrm{~m}$ dpl. Kondisi iklim mikro tempat penelitian akan sangat mempengruhi pertumbuhan tanaman. Suhu di screen house pukul $07.00-10.00$ WIB antara $26.5^{\circ} \mathrm{C}-29.6^{\circ} \mathrm{C}$, sedangkan pada pukul 11.00-13.00 WIB antara $29.0^{\circ} \mathrm{C}-33.4^{\circ} \mathrm{C}$ dan pada pukul $14.00-17.00$ WIB antara $26.3^{\circ} \mathrm{C}-31.3^{\circ} \mathrm{C}$. Kelembaban yang tercatat pukul $07.00-10.00$ WIB antara $79 \%-95 \%$, sedangkan pada pukul $11.00-13.00$ WIB antara $71 \%-89 \%$ dan pada pukul 14.00-17.00 WIB antara 64\%-94\%. Konsisi lingkungan akan sangat mempengaruhi pertumbuhan dan perkembangan tanaman terutama suhu dan kelembaban lingkungan.

\section{Tinggi Tanaman}

Berdasarkan analisis ragam perlakuan substrat yang diberikan tidak memberikan pengaruh yang nyata terhadap tinggi tomat. Hal ini bisa terjadi karena adanya tumbuh tunas baru tanaman tomat setelah mengalami panen dan terjadi penambahan daun. Pada masa vegetatif pertama pada substrat serat aren saja daun tomat hanya sedikit akan tetapi pada saat memasuki vegetatif kedua setelah masa generatif pertama daun tomat semakin bertambah. Tomat merupakan tanaman yang tingginya bisa mencapai 2 meter sehingga tanaman akan tetap bertambah tinggi.

Pengaruh tinggi tanaman berkaitan dengan penambahannya jumlah dan ukuran sel. Laju pembelahan sel serta pembentukan jaringan sebanding dengan pertumbuhan batang. daun dan sistem perakarannya. Pertumbuhan tinggi tanaman menunjukkan aktivitas pembentukan xilem dan pembe-saran sel-sel yang ada yang tumbuh. Aktivitas ini menyebabkan kambium terdorong keluar dan terbentuknya sel-sel baru di luar lapisan-lapisan tersebut sehingga terjadi peningkatan tinggi tanaman (Wasonowati 2011).

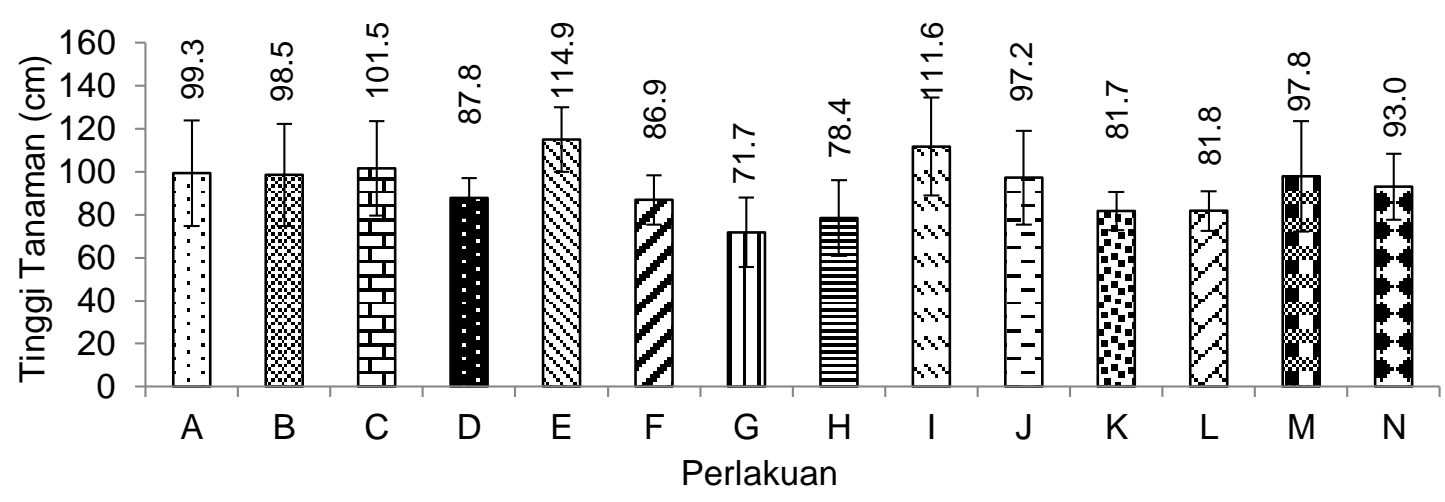

Keterangan:

A : Pasir vulkanik : serat $(1: 3)(\mathrm{v} / \mathrm{v})$

B : Pasir vulkanik : serat $(1: 1)(\mathrm{v} / \mathrm{v})$

C : Pasir vulkanik : serat (3:1) (v/v)

D : Pasir vulkanik

E : Pasir pantai tidak dicuci : serat $(1: 3)(\mathrm{v} / \mathrm{v})$

$\mathrm{F}$ : Pasir pantai tidak dicuci : serat $(1: 1)(\mathrm{v} / \mathrm{v})$

$\mathrm{G}$ : Pasir pantai tidak dicuci : serat $(3: 1)(\mathrm{v} / \mathrm{v})$
$\mathrm{H}$ : Pasir pantai tidak dicuci

I : Pasir pantai dicuci : serat $(1: 3)(\mathrm{v} / \mathrm{v})$

$\mathrm{J}$ : Pasir pantai dicuci : serat $(1: 1)(\mathrm{v} / \mathrm{v})$

$\mathrm{K}$ : Pasir pantai dicuci : serat (3:1) (v/v)

$\mathrm{L}$ : Pasir pantai dicuci

$M$ : Serat batang aren

$\mathrm{N}$ : Arang sekam.

Gambar 1. Rerata tinggi tomat dengan beberapa perlakuan media

\section{Panjang akar}

Panjang akar perlakuan pasir vulkanik dibanding serat batang aren (1:3) yaitu $30.4 \mathrm{~cm},(1: 1)$ yaitu 35.7 $\mathrm{cm},(3: 1)$ yaitu $34.0 \mathrm{~cm}$ dan pasir vulkanik yaitu 44.5 $\mathrm{cm}$. Panjang akar perlakuan pasir vulkanik tidak berbeda nyata dengan substrat serat batang aren saja karena keduanya memiliki sifat yang tidak dapat menahan air banyak sehingga akar tumbuh memanjang untuk mencari nutrisi yang dibutuhkan oleh tanaman. Pasir vulkanik berbeda nyata dengan 
arang sekam karena arang sekam kapasitas menahan airnya lebih tinggi daripada pasir vulkanik sehingga akar tumbuh di bagian atas substrat.

Panjang akar perlakuan pasir pantai asli dibanding serat batang aren (1:3) yaitu $31.3 \mathrm{~cm}$, (1:1) yaitu 24.4 $\mathrm{cm},(3: 1)$ yaitu $24.2 \mathrm{~cm}$ dan pasir pantai asli yaitu 34.0 $\mathrm{cm}$. Panjang akar perlakuan pasir pantai asli dibanding serat batang aren (1:3), (1:1), (3:1) dan pasir pantai asli tidak berbeda nyata dengan arang sekam dan serat batang aren. Penambahan serat batang aren dapat meningkatakan kapasitas menahan air dari pasir pantai dan menurunkan evaporasi.

Panjang akar perlakuan pasir pantai cuci dibanding serat batang aren (1:3) yaitu $30.0 \mathrm{~cm}$, (1:1) yaitu $27.4 \mathrm{~cm}$, (3:1) yaitu $20.0 \mathrm{~cm}$ dan pasir pantai cuci yaitu $28.3 \mathrm{~cm}$. Pasir pantai cuci dsbanding serat batang aren (1:3), (1:1), (3:1) dan pasir pantai cuci tidak berbeda nyata dengan arang sekam karena arang sekam dan pasir patai asli memiliki kapasitas menahan air agak tinggi. Panjang akar perlakuan pasir pantai cuci dibanding serat batang aren (1:3) yaitu $30.0 \mathrm{~cm},(1: 1)$ yaitu $27.4 \mathrm{~cm},(3: 1)$ yaitu $20.0 \mathrm{~cm}$ dan (1:0) yaitu $28.3 \mathrm{~cm}$. Pasir pantai cuci komposisi (1:3), (1:1), (3:1) dan (1:0) tidak berbeda nyata dengan arang sekam karena arang sekam dan pasir patai asli memiliki kapasitas menahan air agak tinggi.

Pasir vulkanik menghasilkan akar yang panjang karena lebih porous daripada pasir pantai sehingga akar dapat menembus ke bawah dengan baik. Pasir vulkanik yang digunakan juga sudah dicuci sehingga tidak mengumpal maka akar dapat menembus substrat dengan baik. Panjang akar antara pasir pantai tanpa cuci dan pasir pantai cuci tidak berbeda nyata karena tekstur keduanya sama sehingga akar tetap bisa tumbuh dengan baik. Kandungan garam pada pasir pantai tanpa cuci tidak mempengaruhi perkembangan akar karena masih bisa ditoleransi. Arang sekam memilki panjang akar yang paling pendek karena arang sekam memiliki pori mikro yang banyak dan kapasitas menahan airnya lebih besar dari pada pasir sehingga akarnya tumbuh baik dibagian atas substrat.

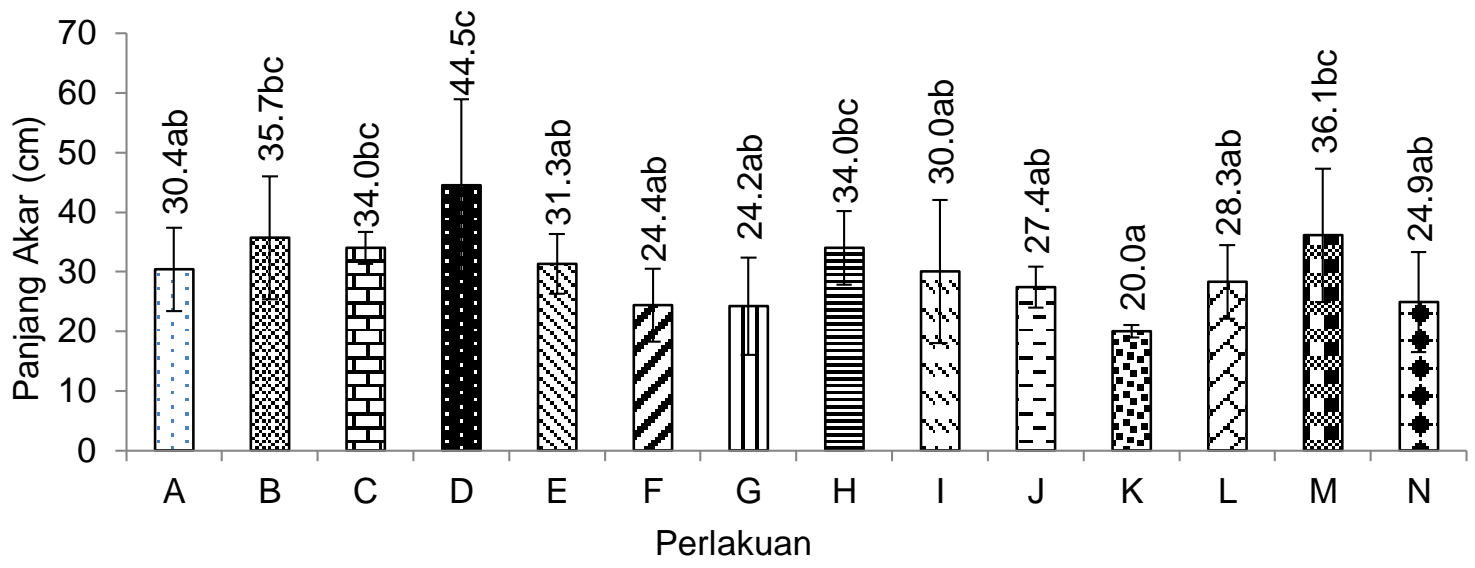

Keterangan: Angka yang diikuti dengan huruf yang sama tidak berbeda nyata berdasarkan DMRT $5 \%$.

A : Pasir vulkanik : serat $(1: 3)(\mathrm{v} / \mathrm{v})$

B : Pasir vulkanik : serat $(1: 1)(\mathrm{v} / \mathrm{v})$

C : Pasir vulkanik : serat $(3: 1)(\mathrm{v} / \mathrm{v})$

D : Pasir vulkanik

E : Pasir pantai tidak dicuci : serat $(1: 3)(\mathrm{v} / \mathrm{v})$

$\mathrm{F}:$ Pasir pantai tidak dicuci : serat $(1: 1)(\mathrm{v} / \mathrm{v})$

G : Pasir pantai tidak dicuci : serat (3:1) (v/v)
$\mathrm{H}$ : Pasir pantai tidak dicuci

I : Pasir pantai dicuci : serat $(1: 3)(\mathrm{v} / \mathrm{v})$

$\mathrm{J}$ : Pasir pantai dicuci : serat $(1: 1)(\mathrm{v} / \mathrm{v})$

$\mathrm{K}$ : Pasir pantai dicuci : serat $(3: 1)(\mathrm{v} / \mathrm{v})$

$L$ : Pasir pantai dicuci

$M$ : Serat batang aren

$\mathrm{N}$ : Arang sekam.

Gambar 2. Rerata panjang akar tomat dengan beberapa perlakuan media

Kemampuan akar untuk menembus sampai ke dasar substrat dipengaruhi oleh aerasi substrat, tekstur substrat dan keporousan substrat serta nutrisi yang tersedia di dalam substrat. Arang sekam merupakan substrat yang dapat menahan nutrisi dengan baik sehingga akar yang tumbuh pada arang sekam tidak terlalu pajang. Kapasitas menahan nutrisi pasir lebih rendah dari pada arang sekam maka akar tanaman pada pasir pantai lebih panjang dari pada arang sekam. Pasir vulkanik lebih porous dari pada pasir pantai sehingga akar tanaman tomat lebih panjang pada substrat pasir vulkanik dibandingkan pada pasir pantai. Kapasitas mehanan air dari pasir vulkanik juga rendah sehingga akar akan tumbuh ke bawah untuk mencari nurtisi yang diperlukan oleh tanaman.
Substrat tanam sangat mempengaruhi pertumbuhan tanaman karena substrat tanam merupakan tempat untuk tegaknya tanaman, tempat penyimpanan air dan nutrisi yang diberikan. Substrat yang baik akan memudahkan akar untuk tumbuh dalam substrat tersebut. Hanifah (2010) menyebutkan bahwa semakin porous substrat akan semakin mudah akar untuk berpenetrasi, serta semakin mudah air dan udara untuk bersirkulasi tetapi semakin mudah pula air untuk hilang dari substrat. Semakin tidak porous substrat semakin sulit akar untuk berpenetrasi, serta semakin sulit air dan udara untuk bersirkulasi tetapi air tidak mudah hilang dari substrat. Menurut Lingga (2002) substrat hidroponik yang digunakan harus yang dapat berfungsi seperti tanah yaitu menyerap nutrisi, air dan oksigen serta mendukung partum-buhan akar tanaman. 
Menurut Ingram et al. (2003), distribusi akar dalam substrat wadah dapat dipengaruhi oleh distribusi ukuran partikel substrat. Substrat dengan kapasitas memegang air yang tinggi mengakibatkan konsentrasi akar di bagian atas wadah, terutama jika substrat di bagian bawah wadah tetap jenuh dalam waktu lama. Substrat serat dan pasir memiliki kapasitas menahan air yang rendah sehingga distribusi akarnya sampai ke bawah untuk mencari nutrisi dan air yang dibutuhkan oleh tanaman. Arang sekam memiliki kapasitas menahan air lebih tinggi dari pada serat batang aren dan pasir sehingga akarnya tidak memanjang ke bawah untuk mencari nutrisi.

\section{Volume akar}

Volume akar perlakuan pasir vulkanik dibanding serat batang aren (1:3) yaitu $12.0 \mathrm{ml},(1: 1)$ yaitu 13.6 $\mathrm{ml}$, (3:1) yaitu $12.3 \mathrm{ml}$ dan pasir vulkanik yaitu 14.3 $\mathrm{ml}$. Pasir vulkanik tidak berbeda nyata dengan substrat serat batang aren saja karena keduanya memiliki sifat yang tidak dapat menahan air banyak sehingga akar tumbuh memanjang untuk mencari nutrisi yang dibutuhkan oleh tanaman. Pasir vulkanik berbeda nyata dengan arang sekam karena arang sekam kapasitas menahan airnya lebih tinggi daripada pasir vulkanik sehingga akarnta tumbuh di bagian atas substrat.
Volume akar perlakuan pasir pantai asli dibanding serat batang aren (1:3) yaitu $9.2 \mathrm{ml},(1: 1)$ yaitu $9.8 \mathrm{ml}$, (3:1) yaitu $10.4 \mathrm{ml}$ dan pasir pantai asli yaitu $18.6 \mathrm{ml}$. Pasir pantai asli komposisi (1:0) berbeda nyata substrat serat batang aren karena pasir pantai asli memiliki kapasitas menahan air yang lebih tinggi sehingga banyak bulu akar yang tumbuh untuk menyerap nutrisi yang dibutuhkan tanaman. Pasir pantai asli berbeda nyata dengan pasir pantai asli dibanding serat batang aren (1:3), (1:1) dan (3:1) hal ini bisa terjadi karena akar pada pasir pantai asli dibanding serat batang aren (1:3), (1:1) dan (3:1) tidak banyak memiliki bulu-bulu akar tetapi penyerapan nutrisinya optimal dan digunakan dengan baik untuk fotosintesis sehingga dapat menghasilkan tinggi dan jumlah saun tomat yang sama dengan pasir.

Volume akar perlakuan pasir pantai cuci dibanding serat batang aren (1:3) yaitu $9.2 \mathrm{ml},(1: 1)$ yaitu 13.2 $\mathrm{ml},(3: 1)$ yaitu $8.7 \mathrm{ml}$ dan pasir pantai cuci yaitu 19.0 $\mathrm{ml}$. Pasir pantai cuci berbeda nyata dengan komposisi (1:3) dan (3:1) hal ini bisa terjadi karena akar pada pasir pantai cuci dibanding serat batang aren (1:3) dan (3:1) tidak banyak memiliki bulu-bulu akar tetapi penyerapan nutrisinya optimal dan digunakan dengan baik untuk fotosintesis sehingga dapat menghasilkan tinggi dan jumlah daun tomat yang sama dengan pasir.

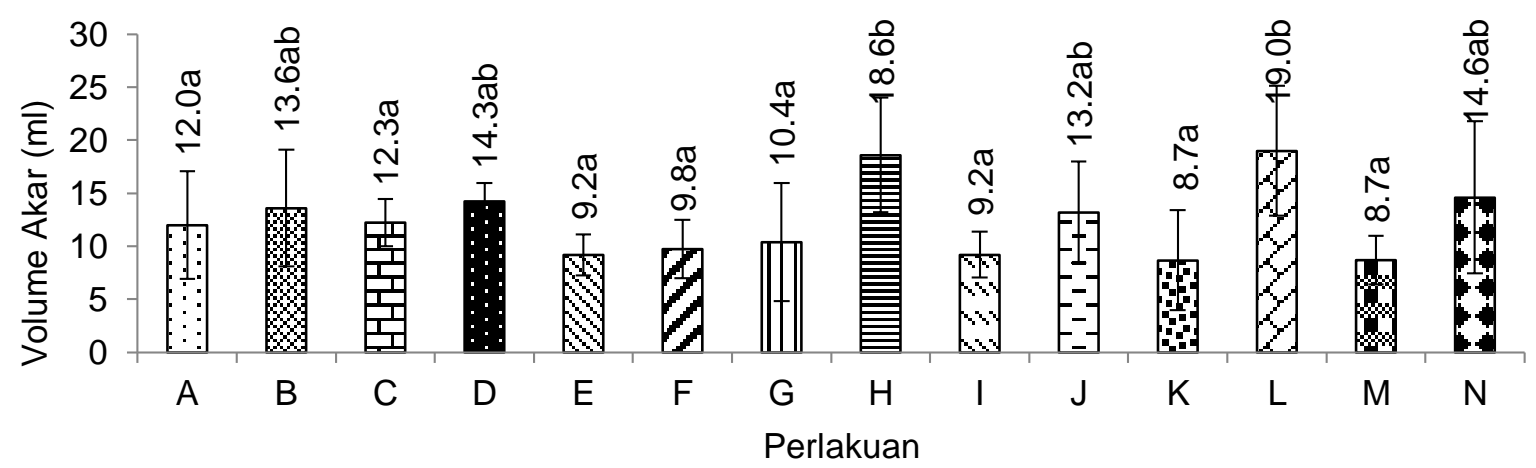

Keterangan: Angka yang diikuti dengan huruf yang sama tidak berbeda nyata berdasarkan DMRT $5 \%$.
A : Pasir vulkanik : serat $(1: 3)(\mathrm{v} / \mathrm{v})$
B : Pasir vulkanik : serat $(1: 1)(\mathrm{v} / \mathrm{v})$
C : Pasir vulkanik : serat $(3: 1)(\mathrm{v} / \mathrm{v})$
D : Pasir vulkanik
E : Pasir pantai tidak dicuci : serat $(1: 3)(\mathrm{v} / \mathrm{v})$
$\mathrm{F}:$ Pasir pantai tidak dicuci : serat $(1: 1)(\mathrm{v} / \mathrm{v})$
$\mathrm{G}$ : Pasir pantai tidak dicuci : serat $(3: 1)(\mathrm{v} / \mathrm{v})$

$\mathrm{H}$ : Pasir pantai tidak dicuci

I : Pasir pantai dicuci : serat $(1: 3)(\mathrm{v} / \mathrm{v})$

$\mathrm{J}$ : Pasir pantai dicuci : serat $(1: 1)(\mathrm{v} / \mathrm{v})$

$\mathrm{K}$ : Pasir pantai dicuci : serat $(3: 1)(\mathrm{v} / \mathrm{v})$

$\mathrm{L}$ : Pasir pantai dicuci

$M$ : Serat batang aren

$\mathrm{N}$ : Arang sekam.

\section{Gambar 3. Rerata volume akar tomat dengan beberapa perlakuan media}

Menurut Elly (1993) pasir memiliki kelemahan yaitu dalam penggunaannya sebagai substrat tanam perlu dibersihkan terlebih dahulu serta memiliki kandungan unsur hara yang sedikit. Pair vukanik yang digunakan dicuci terlebih dahulu sampai debu-debunya hilang sehingga apabila sisiram tidak keras maka dapat dengan mudah ditembus akar. Pasir pantai tekturnya sangat lebut denga ukuran pasir yang sangat halus juga mendukung perkembangan akar.

Serat batang aren banyak memiliki pori makro sehingga nutrisi yang disiramkan lebih banyak yang lolos dari pada yang ditahan oleh substrat. Serat batang aren tanpa dikombinasikan dengan substrat yang lain kurang baik apabila digunakan sebagai substrat tanam maka perlu dikombinasikan dengan substrat yang memiliki pori mikro sehingga dapat meningkatkan daya menahan air dan nutrisi. Pasir memiliki daya menahan nutrisi lebih besar daripada serat aren sehingga akar tanaman dapat memanfaatkan nutrisi dengan baik. Jumlah ruang pori substrat adalah karakteristik fisik penting yang mempengaruhi air dan penyerapan nutrisi dan gas pertukaran dengan sistem akar (Sahin et al. 2002). Pasir dikombi-nasikan dengan serat aren dapat menurunkan suhunya ketika siang hari dan mengurangi evaporasi pada pasir. 
Menurut Harjoko (2007) akar yang memiliki banyak cabangnya akan memudahkan untuk mengambil nutrisi yang diberikan, apabila penyerapan nutrisi berjalan dengan baik, maka tanaman akan tumbuh dengan baik. Gardner et al (1991) mengatakan bahwa kelembaban dan aerasi yang baik dari suatu substrat sangat diperlukan untuk pertumbuhan akar yang maksimal karena efektifitas pemupukan atau pemberian larutan nutrisi dipengaruhi oleh substrat tanam. Terganggunya respirasi akar dapat menyebabkan akar tidak berkembang dengan baik sehingga akar kurang mampu menyerap unsur hara yang diberikan.

\section{Rasio akar tajuk}

Rasio akar batang merupakan hasil pembagian dari berat kering akar dibagi berat kering batang. Hasil analisis ragam menunjukkan bahwa perlakuan yang diberikan tidak berpengaruh nyata terhadap rasio akar tajuk. Hal ini bisa terjadi karena hasil fotosintesis tidak hanya disimpan dalam bentuk berat kering tajuk saja akan tetapi juga disimpan dalam bentuk buah. Nilai rasio akar batang yang rendah berarti akar yang tidak terlalu besar menghasilkan tajuk yang besar. Fotosintesis berjalan dengan lancar dan didukung dengan akar menyerap nutrisi substrat dengan baik. Akar berkembang dengan baik untuk menyerap nutrisi yang digunakan untuk fotosintesis yang tidak hanya disimpan dalam bentuk biomassa tetapi juga dalam bentuk buah.

Pertumbuhan juga dapat diukur dari pertambahan biomassa yang dihasilkan tanaman. Pendekatan yang digunakan untuk pengukuran biomassa tanaman adalah menimbang berat basah dan berat kering tanaman. Berat kering lebih disukai untuk menaksir pertumbuhan tanaman, karena mencerminkan akumulasi senyawa organik yang disintesis tanaman dari senyawa anorganik. Unsur hara yang diserap tanaman dari lingkungan juga memberi kontribusi pada berat kering tanaman (Sitompul dan Guritno 1995).

Pada akhir masa tanaman mengalami senesen selain itu akar yang biomassanya kecil bisa menghasilkan tanaman yang kecil dan akar yang biomassanya besar menghasilkan tanaman yang besar pula. Senesen pada tumbuhan dapat mengikuti beberapa pola. Pada tanaman tomat ini mengalami senesen yang meliputi hanya daun bagian bawah (daun tua) sedang daun bagian atas dan organ tumbuhan lain tetap hidup (Purnomo et al. 2010). Pada saat tanaman dipanen keseluruhan sebagain daunnya sudah mongering karena sudah mengalami senesen sehingga berat segar tanaman tidak berbeda nyata antar perlakuannya. Selain itu karena sebagian tanaman masih segar dan kadungan air di dalamnya masih tinggi.

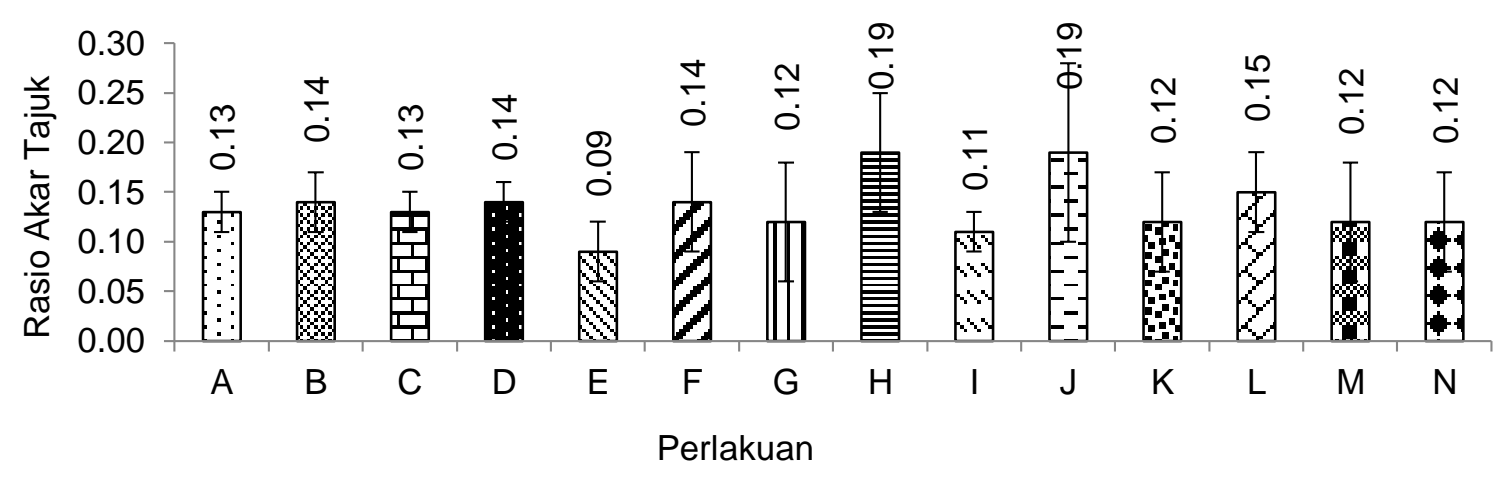

Keterangan:

A : Pasir vulkanik : serat $(1: 3)(\mathrm{v} / \mathrm{v})$

$\mathrm{H}$ : Pasir pantai tidak dicuci

$B$ : Pasir vulkanik : serat $(1: 1)(\mathrm{v} / \mathrm{v})$

I : Pasir pantai cuci : serat (1:3) (v/v)

C : Pasir vulkanik : serat $(3: 1)(\mathrm{v} / \mathrm{v})$

D : Pasir vulkanik

E : Pasir pantai tidak dicuci : serat $(1: 3)(\mathrm{v} / \mathrm{v})$

$\mathrm{F}$ : Pasir pantai tidak dicuci : serat $(1: 1)(\mathrm{v} / \mathrm{v})$

G : Pasir pantai tidak dicuci : serat (3:1) (v/v)

$\mathrm{J}$ : Pasir pantai cuci : serat $(1: 1)(\mathrm{v} / \mathrm{v})$

$\mathrm{K}$ : Pasir pantai cuci : serat $(3: 1)(\mathrm{v} / \mathrm{v})$

$L$ : Pasir pantai dicuci

$\mathrm{M}$ : Serat batang aren

$\mathrm{N}$ : Arang sekam.

Gambar 4. Rerata rasio akar tajuk dengan beberapa perlakuan media

\section{Berat buah per tanaman}

Berat buah per tanaman perlakuan pasir vulkanik dibanding serat batang aren (1:3) yaitu 311.2 gram, (1:1) yaitu 367.3 gram, (3:1) yaitu 343.3 gram dan pasir vulkanik yaitu 363.6 gram. Pasir vulkanik dibanding serat batang aren (1:3), (1:1), (3:1) dan pasir vulkanik berbeda nyata dengan perlakuan substrat arang sekam, hal ini bisa terjadi karena pada pada perlakuan arang sekam banyak yang terkena busuk pantat buah. Perlakuan pasir vulkanik dibanding serat batang (1:1) dan (1:0) menghasilkan buah yang berbeda nyata dengan perlakuan serat batang aren karena kapasitas menahan air dari serat batang aren yang rendah sehingga nutrisi yang dibutuhkan tanaman untuk berfotosintesis tidak mencukupi, selain itu serat batang aren mudah ditumbuhi oleh jamur sehingga sebagian nutrisi yang diberikan juga digunakan atau diserap oleh jamur yang tumbuh tersebut.

Berat buah per tanaman perlakuan pasir pantai asli dibanding serat batang aren (1:3) yaitu 330.3 gram, (1:1) yaitu 422.9 gram, (3:1) yaitu 399.8 gram dan pasir pantai asli yaitu 389.5 gram. Pasir pantai asli dibanding serat batang aren (1:3), (1:1), (3:1) dan 
pasir pantai asli berbeda nyata dengan perlakuan substrat arang sekam, hal ini bisa terjadi karena pada pada perlakuan arang sekam banyak yang terkena busuk pantat buah. Perlakuan pasir pantai asli dibanding serat batang aren (1:1), (1:3) dan pasir pantai asli menghasilkan buah yang berbeda nyata dengan perlakuan serat batang aren karena kapasitas menahan air dari serat batang aren yang rendah sehingga nutrisi yang dibutuhkan tanaman untuk berfotosintesis tidak mencukupi, selain itu serat batang aren mudah ditumbuhi oleh jamur sehingga sebagian nutrisi yang diberikan juga digunakan atau diserap oleh jamur yang tumbuh tersebut.

Berat buah pertanaman perlakuan pasir pantai cuci dibanding serat abating aren (1:3) yaitu 363.7 gram, (1:1) yaitu 470.3 gram, (3:1) yaitu 397.5 gram dan pasir pantai cuci yaitu 445.5 gram. Pasir pantai asli dibanding serat batang aren (1:3), (1:1), (3:1) dan pasir pantai cuci berbeda nyata dengan perlakuan substrat arang sekam, hal ini bisa terjadi karena pada pada perlakuan arang sekam banyak yang terkena busuk pantat buah. Perlakuan pasir pantai asli dibanding serat batang aren(1:3), (1:1), (1:3) dan pasir pantai cuci menghasilkan buah yang berbeda nyata dengan perlakuan serat batang aren karena kapasitas menahan air dari serat batang aren yang rendah sehingga nutrisi yang dibutuhkan tanaman untuk berfotosintesis tidak mencukupi.

Hasil berat buah arang sekam sangat rendah karena buah banyak yang mengalami busuk pantat buah. Blossom end-rot ialah kerusakan berupa busuk pantat buah dikarenakan kurang unsur $\mathrm{Ca}$ (Ho dan White 2005). Penelitian ini menggunakan nutrisi dengan kandungan $\mathrm{Ca}$ cukup tinggi, sehingga kemungkinan kekurangan $\mathrm{Ca}$ sangat kecil. Menurut Sideman (2015) rekomendasi yang paling umum untuk mencegah BER adalah fokus pada pengelolaan air mencoba untuk meminimalkan stres kekeringan atau genangan air. Penggunaan substrat arang sekam dengan kapasitas menahan air yang tinggi dan polybag yang digunakan dilubangi setelah 6 MST membuah subtract jenuh air sehingga menimbulkan BER pada tomat akibat stress genangan.

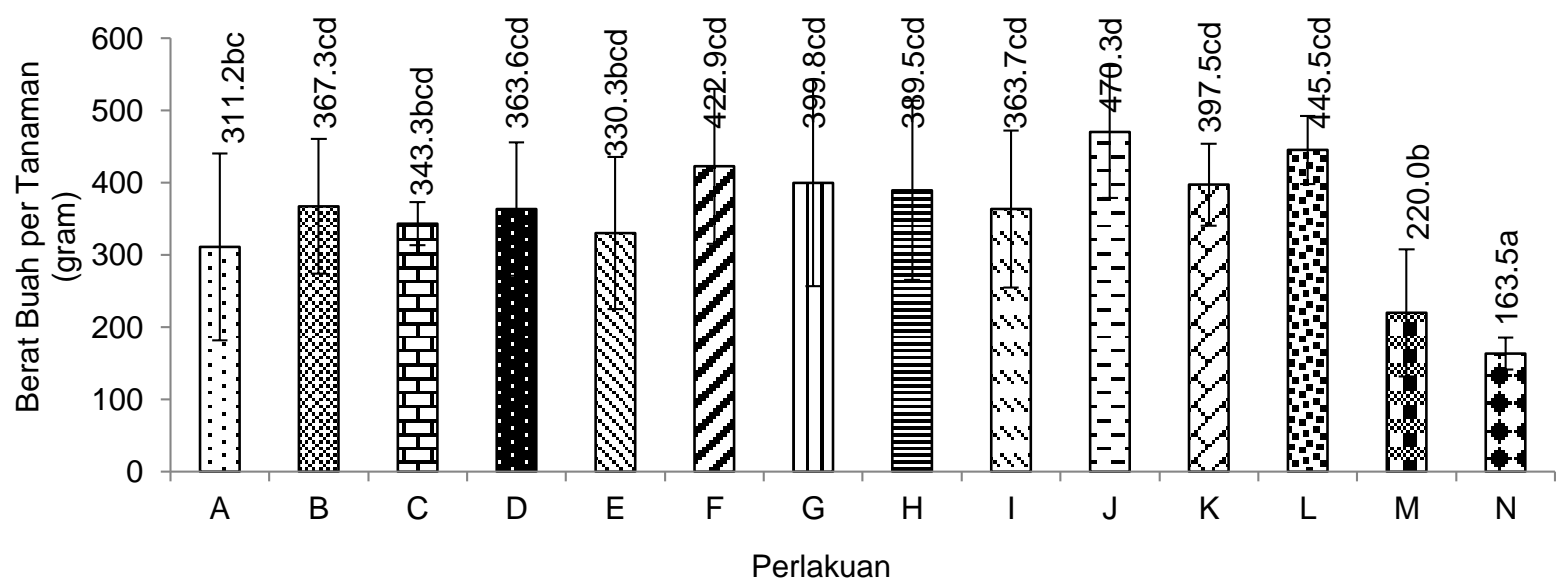

Keterangan: Angka yang diikuti dengan huruf yang sama tidak berbeda nyata berdasarkan DMRT $5 \%$.
A : Pasir vulkanik : serat $(1: 3)(\mathrm{v} / \mathrm{v})$
B : Pasir vulkanik : serat $(1: 1)(\mathrm{v} / \mathrm{v})$
$\mathrm{H}$ : Pasir pantai tidak dicuci
C : Pasir vulkanik: serat $(3: 1)(\mathrm{v} / \mathrm{v})$
I : Pasir pantai dicuci : serat (1:3) $(\mathrm{v} / \mathrm{v})$
D : Pasir vulkanik
E : Pasir pantai tidak dicuci : serat $(1: 3)(\mathrm{v} / \mathrm{v})$
F : Pasir pantai tidak dicuci : serat $(1: 1)(\mathrm{v} / \mathrm{v})$
G : Pasir pantai tidak dicuci : serat $(3: 1)(\mathrm{v} / \mathrm{v})$
$\mathrm{J}$ : Pasir pantai dicuci : serat $(1: 1)(\mathrm{v} / \mathrm{v})$
$\mathrm{K}$ : Pasir pantai cuci : serat $(3: 1)(\mathrm{v} / \mathrm{v})$
$L$ : Pasir pantai dicuci
$M$ : Serat batang aren
$\mathrm{N}$ : Arang sekam.
Gambar 5. Rerata berat buah per tanaman dengan beberapa perlakuan

Menurut Mukhid (2005) pasir mempunyai kendala karena pada aspek strukturnya yang jelek, berbutir tunggal lepas-lepas, mempunyai berat volume tinggi, kemampuan menyerap dan menyimpan air rendah sehingga kurang memadai untuk mendukung usaha bercocok tanam. Penambahan serat batang aren dapat meningkatkan penyerapan dan penyimpanan nutrisi. Pasir vuklanik, pasir pantai asli dan pasir panti cuci menghasilkan buah yang cukup tinggi karena penyiraman dilakukan 2 kali sehiari sehingga nutrisi yang dibutuhkan selalu tersedia, akan tetapi apabila karena sedikit atau tidak ada sifat yang baik tidak akan berguna.

Hasil produksi tomat pada penelitian ini belum sesuai dengan potensi produksinya yaitu mencapai 3 $\mathrm{kg}$ per tanaman hal ini disebabkan oleh suhu Kombinasi Jenis Pasir dengan Serat Batang Aren serta Shufiyati Muniroh, Dwi Harjoko, Sumiyati penyiraman dilkakukan sehari sekali tanaman akan layu pada siang hari karena nutrisi dan air yang diberikan banyak yang menguap. Menurut Khalaj (2007) mengatakan bahwa bahan organik dan kapasitas tukar kation tinggi meningkatkan penyerapan dan penyimpanan nutrisi, air dan juga dengan menciptakan kondisi yang cocok untuk pertumbuhan akar tanaman, dapat meningkatkan karakteristik kualitatif dan kuantitatif bunga. Jika gambut telah digunakan sendiri, karena ventilasi menekan dan me-ngurangi dan pasir atau perlit lingkungan yang kurang sesuai dengan syarat tumbuh tomat. Menurut Sunarjono (1977) Suhu udara optimal untuk pertumbuhan tanaman tomat antara $18^{\circ}-25^{\circ} \mathrm{C}$ dengan keadaan cuaca cerah. Tingginya suhu udara juga mengakibatkan suhu tanah tinggi yang tidak 
Agrosains 17(1): 14-20, 2015; ISSN: 1411-5786

sesuai dengan syarat pertumbuhan tanaman tomat $15-16^{\circ} \mathrm{C}$.

\section{KESIMPULAN DAN SARAN}

\section{Kesimpulan}

Berdasarkan hasil dari penelitian maka dapat disimpulkan sebagai berikut :

1. Perlakuan substrat pasir vulkanik, pasir pantai asli dan pasir pantai cuci menghasil-kan pertumbuhan dan hasil yang baik pada tomat apabila penyiraman sering dilakukan agar tanaman tidak layu.

2. Perlakuan substrat serat batang aren menghasilkan pertumbuhan yang kurang baik terhadap akar dan hasil buah tomat.

3. Perlakuan pasir vulkanik, pasir pantai asli dan pasir pantai cuci dibanding serat batang aren (1:1) menghasilkan pertumbuhan dan hasil yang baik pada tanaman tomat.

\section{Saran}

Saran yang diberikan dalam penelitian ini adalah serat batang aren yang digunakan sebaiknya direndam yang lebih lama, apabila digiling hasil ukurannya lebih kecil lagi sehingga dapat meningkatkan kapasitas menahan air.

\section{DAFTAR PUSTAKA}

Elly. 1993. Hidroponik kangkung di halaman rumah. J Hort Pengembangan Pertanian 2(1): 12-14.

Gardner FP, Pearce RB, Mitchell RL. 1991. Fisiologi tanaman budidaya. Diterjemahkan oleh H. Susilo. Jakarta (ID): UI Press.

Hanifah KA. 2010. Dasar-dasar IImu tanah. Jakarta (ID): PT Raja Grafindo Persada.

Harjoko D. 2007. Studi macam sumber air dan pH larutan nutrisi terhadap pertumbuhan dan hasil tanaman sawi (Brassica juncea) secara hidroponik NFT. Makalah Seminar Nasional Hortikultura. Fakultas Pertanian UNS Surakarta.

Ho LC, White PJ. 2005. A cellular hypothesis for the induction of blossom-end rot in tomato fruit. Annals of Botany 95: 571-581.

Ingram DL, Henley RW, Yeager TH. 2003. Growth media for container grown ornamental plants. miami-dade.ifas.ufl.edu. Diakses 20 Mei 2015.

Khalaj M. 2007. Gerbera cultivation guide. National Research Station of Flowers and Ornamental Plants Publications. Bulletin No. 86.394. Markazi, Iran.

Lingga P. 2002. Hidroponik bercocok tanam tanpa tanah. Jakarta (ID): Penebar Swadaya.

Mukhid S. 2005. Pengaruh pemberian lapisan lempung terhadap peningkatan lengas tanah pada lahan berpasir. http://www.iptek.net.id. Diakses 20 Mei 2015.

Sahin U, Anapali O, Ercisli S. 2002. Physico-chemical and physical properties of some substrates used in horticulture. Gartenbauwissenschaft 67: 55-60.

Sideman B. 2015. Managing blossom-end rot. department of agriculture and n.h. counties cooperating. University of New Hampshire, U.S.

Sitompul SM, Guritno B. 1995. Analisis pertumbuhan tanaman. Yogyakarta (ID): Gadjah Mada University Press.

Sunarjono. 1977. Budidaya tomat. Jakarta (ID): PT Soeroengan.

Wasonowati C. 2011. Meningkatkan pertumbuhan tanaman tomat (Lycopersicum esculentum) dengan sistem budidaya hidroponik. J Agro 4(1).

Yuwono NW. 2009. Membangun kesuburan tanah di lahan marginal. J IImu Tanah dan Lingkungan 9 (2) $137-141$. 